\title{
Chemical Properties Effects on Boosting the Compounds Manufacturing Process
}

\section{Prof. Parvaneh Basaligheh}

University of Tech and Management, Malaysia pbasaligeh@utmcc.my

\section{Abstract}

It is a thought of utilizing earth cordial materials in concrete, to make the framework logically legitimate. These are alluded to as the pointless vitality in their creation and delivers less $\mathrm{CO} 2$ which causes Global Warming. Solid squanders like slag, power plant squanders, reused solid, mining and quarrying squanders, squander glass, consumed dirt, sawdust, combustor debris and foundry sand.

Keywords: Recycled concrete Lime, clay etc.

\section{INTRODUCTION}

Green cement is an eco-accommodating in light of the fact that it is made by the solid waste so it is additionally called eco-accommodating cement. Green concrete is constantly and moreover unobtrusive to make, considering the way that for example, squander things are used as a fractional substitute for solid, charges for the expulsion of waste are kept away from, and power is more noteworthy. Its creation decreases concrete admission, and its significant crude materials incorporate disposed of mechanical squanders like impact heater slag and fly debris. Carbon dioxide discharged all through the developed procedure is extensively decreased. The concrete has thought of specific equations where Saltwater or even Wastewater can be successfully utilized at places where new water isn't in plenitude. Green concrete will offer ease and quality advantages in future. 


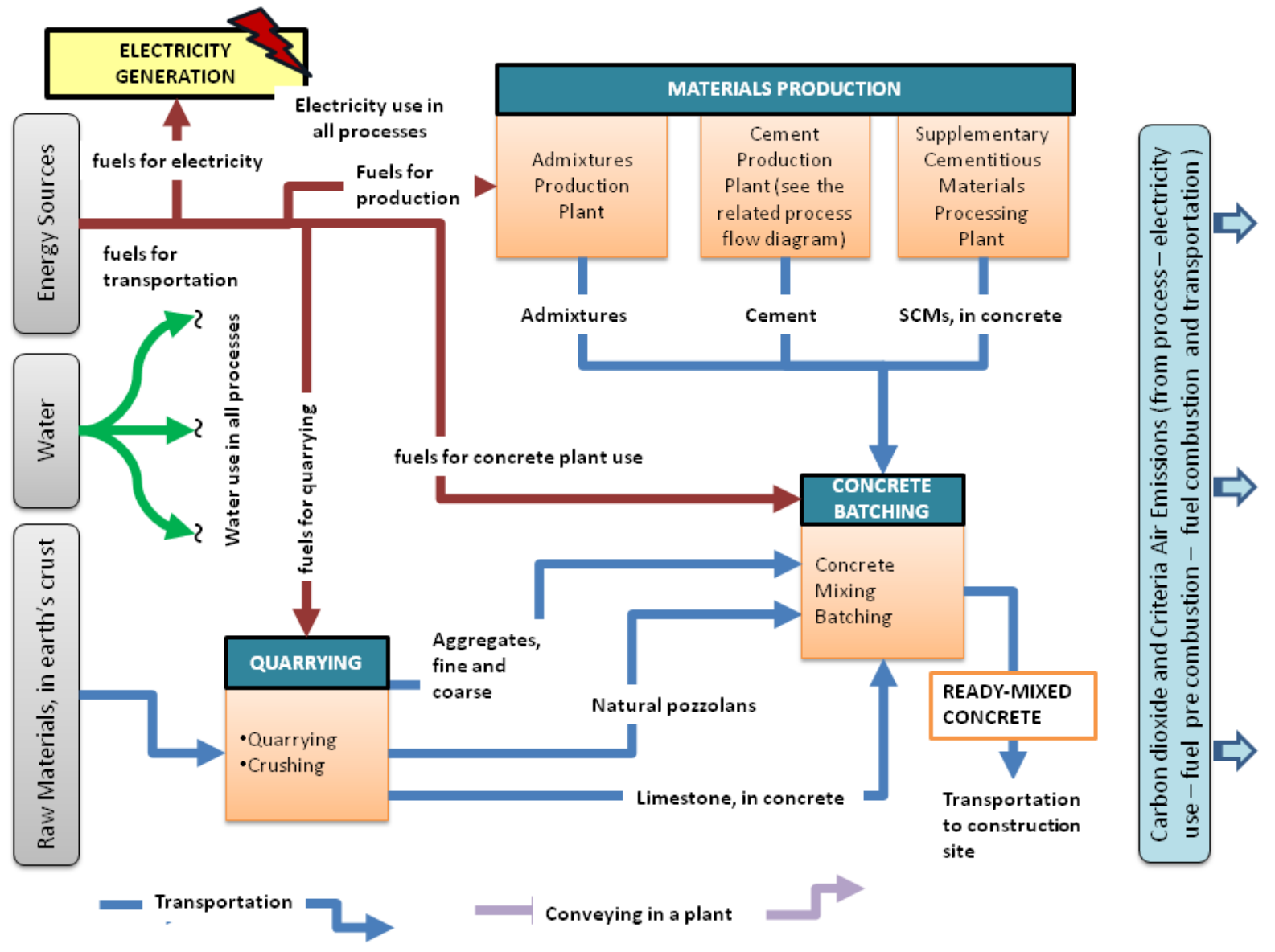

Fig 1: green cement manufacture process

Table 1

Physical Properties of Quarry Rock Dust

\begin{tabular}{|l|c|}
\hline \multicolumn{1}{|c|}{ Property } & $\begin{array}{c}\text { Quarry } \\
\text { Rock Dust }\end{array}$ \\
\hline Specific gravity & $2.54-2.60$ \\
\hline Bulk relative density $(\mathrm{kg} / \mathrm{m} 3)$ & $1720-1810$ \\
\hline Absorption (\%) & $1.20-1.50$ \\
\hline Moisture content $(\%)$ & Nil \\
\hline Fine particles less than $0.075 \mathrm{~mm} \mathrm{( \% )}$ & $12-15$ \\
\hline Sieve analysis & Zone II \\
\hline
\end{tabular}


Table 2

Chemical Properties of Fly Ash

\begin{tabular}{|c|l|c|c|}
\hline $\begin{array}{c}\text { Sl. } \\
\text { No. }\end{array}$ & \multicolumn{1}{|c|}{ Test Conducted } & $\begin{array}{c}\text { Observed } \\
\text { Values (\%) }\end{array}$ & $\begin{array}{c}\text { Requirement as } \\
\text { per IS:1320-1981 }\end{array}$ \\
\hline 1 & Loss of Ignition & 2.32 & $5.0($ max) \\
\hline 2 & Silica as $\mathrm{SiO}_{2}$ & 42.04 & $\begin{array}{c}\mathrm{SiO}_{2}+\mathrm{Fe}_{2} \mathrm{O}_{3}+ \\
\mathrm{Al}_{2} \mathrm{O}_{3}=70\end{array}$ \\
\hline 3 & Iron as $\mathrm{Fe}_{2} \mathrm{O}_{3}$ & 4.40 & - \\
\hline 4 & Alumina as $\mathrm{Al}_{2} \mathrm{O}_{3}$ & 33.60 & - \\
\hline 5 & Calcium as $\mathrm{CaO}$ & 12.73 & - \\
\hline 6 & Magnesium as $\mathrm{MgO}$ & 0.00 & 5.0 \\
\hline 7 & Sulphate as $\mathrm{SO}_{3}$ & 0.40 & 3.0 \\
\hline 8 & Chloride & - & \\
\hline 9 & Lime Reactivity & $4 \mathrm{~N} / \mathrm{mm}^{2}$ & 4.5 \\
\hline
\end{tabular}

Highly Resistant to Water, Acids, Corrosion, Sulfates

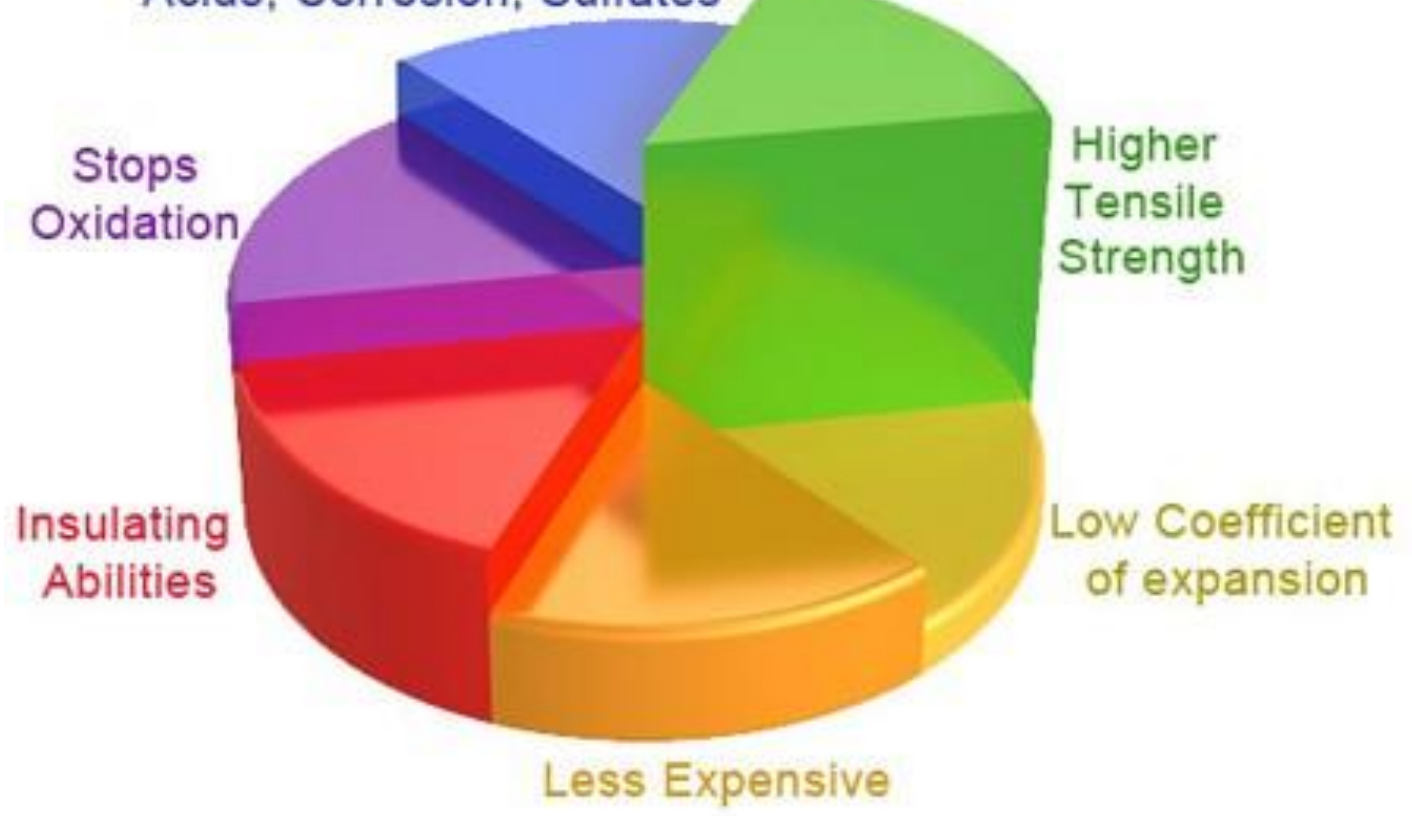

Fig2: benefits of green cement 


\section{ADVANTAGES OF GREEN CEMENT}

\begin{tabular}{|c|c|c|}
\hline S.no. & concept & Advantages \\
\hline 1. & Workability & $\begin{array}{l}\text { Green concrete having better workability than } \\
\text { conventional concrete. }\end{array}$ \\
\hline 2. & $\mathrm{CO}_{2}$ Emission & $\begin{array}{l}\text { Reduction of the concrete industry's CO2-emmision by } \\
30 \% \text {. }\end{array}$ \\
\hline 3. & Waste Product & $\begin{array}{l}\text { Increased concrete industry's use of waste products by } \\
20 \% \text {. }\end{array}$ \\
\hline 4. & $\begin{array}{l}\text { environmental } \\
\text { pollution }\end{array}$ & $\begin{array}{l}\text { NO environmental pollution and sustainable } \\
\text { development. }\end{array}$ \\
\hline 5. & maintenance & Green concrete requires low maintenance and repairs. \\
\hline 6. & resistant & Good thermal resistant and fire resistant. \\
\hline 7. & $\begin{array}{l}\text { Compressive strength } \\
\text { behavior }\end{array}$ & $\begin{array}{l}\text { Compressive strength behavior of concrete with water } \\
\text { cement ratio is similar to conventional concrete. }\end{array}$ \\
\hline 8. & $\begin{array}{l}\text { strength, durability, } \\
\text { and elasticity }\end{array}$ & $\begin{array}{l}\text { The product has higher strength, durability, and elasticity } \\
\text { which makes the concrete everlasting and low } \\
\text { maintenance. }\end{array}$ \\
\hline 9. & less energy & $\begin{array}{l}\text { Green Cement requires significantly less energy to } \\
\text { produce, thus leaving a substantially smaller carbon } \\
\text { footprint. }\end{array}$ \\
\hline 10. & cost-effective & $\begin{array}{l}\text { The manufacturing process of Green cement does not } \\
\text { involve the use of large energy-intensive kilns which } \\
\text { makes it cost-effective. }\end{array}$ \\
\hline
\end{tabular}

\section{GLOBAL GREEN CEMENT MARKET SHARE, BY APPLICATION 2025}

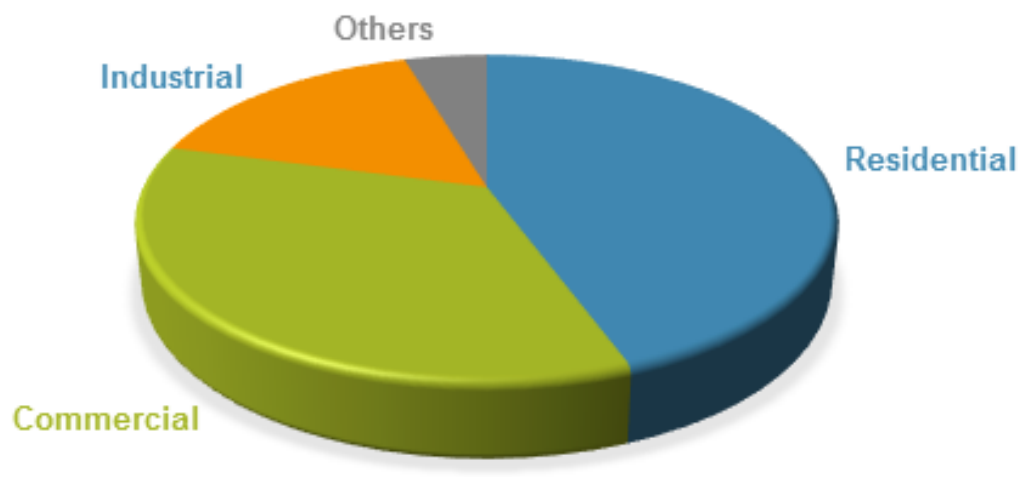




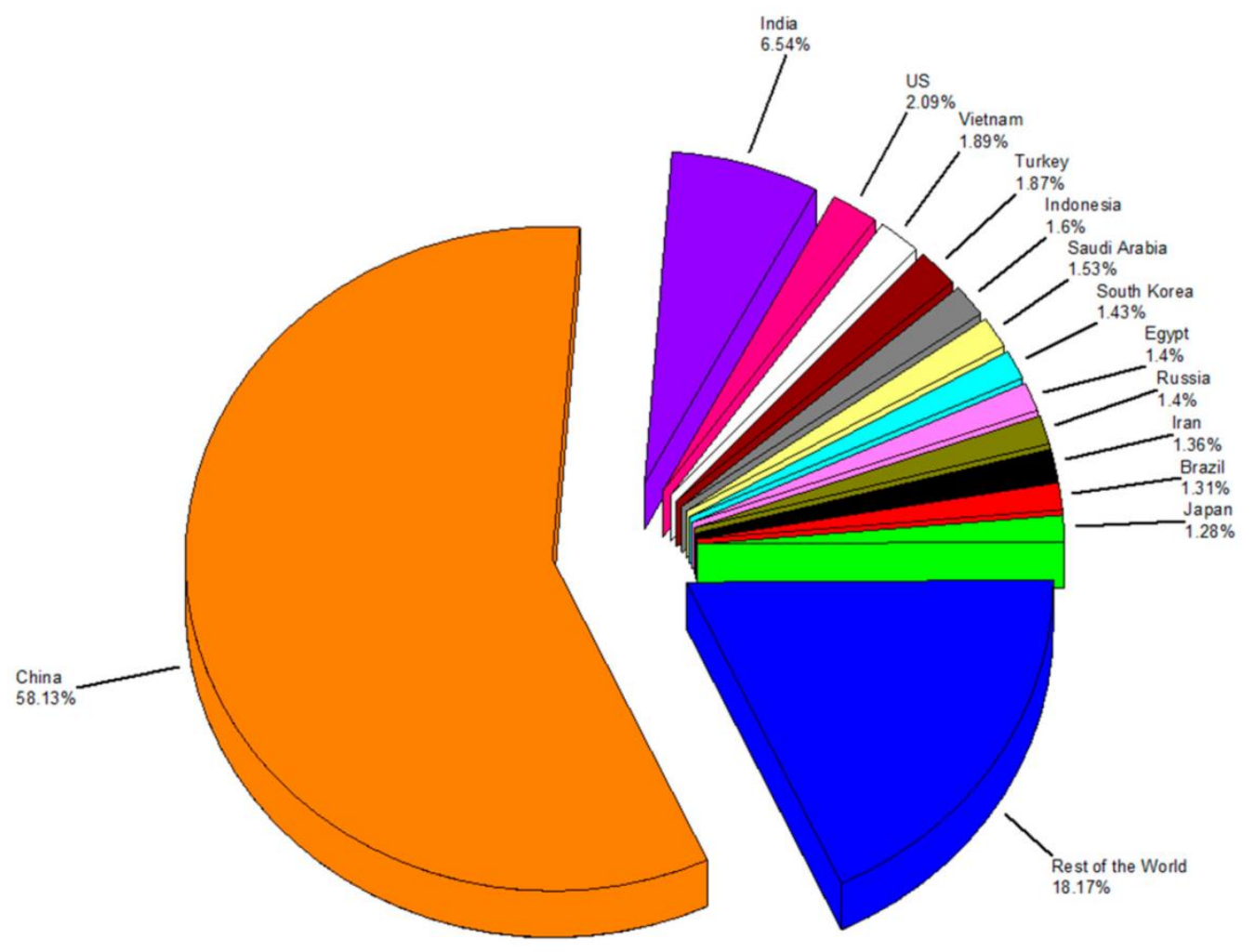

Fig 3. Global cement production

\section{CONCLUSION}

This paper shows that it won't just diminish the emanation of $\mathrm{CO} 2$ in condition and natural effect however it is additionally financially savvy to deliver in future. In this paper we have talked about the different compound arrangement of green concrete with advantages and confinements.

\section{REFERENCES}

[1]. Swamy RN, Mehmod HB. Mix proportions and strength characteristics of concrete containing 50\% low calcium fly ash. In: Malhotra VM, editor. Proceedings of the second international congress on fly ash, silica fume, slag and national pozzolanas in concretes, Madrid, ACJ SP 91, vol. 1; 1986. p. 41332.

[2]. Orsos, T., 'BST: The Lightweight concrete aggregate', Concrete Institute of Australia seminar on Special Use Concretes, Melbourne, 1992.

[3]. Ahmed E. Ahmed and Ahmed A. E. kourd.1989. Properties of concrete incorporating natural and crushed stone very fine sand.ACI Material journal.86 (4):417-424. 
[4]. Rebeiz, K. S., 1996. Precast use of polymer concrete using unsaturated polyester resin based on recycled PET waste. Construction and Building Materials 10 (3), 215-220.

[5] T. Punmatharith, M. Rachakornkij, A. Imyim, and M.Wecharatana, "Co-processing of grinding sludge as alternative raw material in portland cement clinker production," Journal of Applied Sciences, vol. 10, no. 15, pp. 1525-1535, 2010.

[6] D. N. Huntzinger and T. D. Eatmon, "A life-cycle assessment of Portland cement manufacturing: comparing the traditional process with alternative technologies," Journal of Cleaner Production, vol. 17, no. 7, pp. 668-675, 2009.

[7] K. Ganesan, K. Rajagopal, and K. Thangavel, "Evaluation of bagasse ash as supplementary cementitious material," Cement and Concrete Composites, vol. 29, no. 6, pp. 515-524, 2007.

[8] S. Sinthaworn and P. Nimityongskul, "Quick monitoring of pozzolanic reactivity of waste ashes," Waste Management, vol.29, no. 5, pp. 1526-1531, 2009. 